\title{
Analisis Kondisi Atmosfer Terkait Siklon Tropis Pabuk Serta Pengaruhnya Terhadap Tinggi Gelombang di Perairan Kepulauan Riau
}

\author{
Diana Cahaya Siregar', Vivi Putrima Ardah', Arlin Martha Navitri²
}

\author{
'Stasiun Meteorologi Raja Haji Fisabilillah Tanjungpinang \\ Jl. Adi Sucipto Area Km. 12,5, Area Perkantoran Bandara RHF, Tanjungpinang, 29125 \\ 2Stasiun Meteorologi Kertajati Majalengka \\ Jl. Letnan Angkat Arzain No. 28, Jatiwangi, Majalengka, Jawa Barat, 45454 \\ Email corresponding: siregardianacahaya@gmail.com
}

\begin{abstract}
Tropical cyclones is a synoptic scale low pressure system which can have an impact, both directly or indirectly to its traversed area. On January 1 to 6, 2019, Pabuk tropical cyclone was active on the South China Sea which its movement was to the west with its maximum wind speed was 64 knots. The aim of this study was to know the impact of Pabuk tropical cyclone to the atmospheric condition and sea wave on the Riau Islands region. This study used convective index analysis using IR1 channel of Himawari-8 satellite imagery and rainfall distribution data from rainfall observation by meteorological stations which are in the Riau Islands region. European Center for MediumRange Weather Forecast (ECMWF) reanalysis data likes relative humidity, vertical velocity, and divergence was used to describe the atmospheric condition during the life time of Pabuk tropical cyclone. Wavewatch-III data was used to describe the condition of sea waves on the Riau Islands region. The results showed that Pabuk tropical cyclone had an impact on the growth of convective clouds which it caused the light to moderate rainfall quite evenly in the Riau Islands region. Besides, it was impact to the potential of high waves reached 4.5 meters on the northern of Anambas Sea and 7.0 meters on the north-eastern of Natuna Sea.
\end{abstract}

Key words: Tropical cyclone, satellite imagery, wave height

\begin{abstract}
Abstrak
Siklon tropis merupakan sistem tekanan rendah berskala sinoptik yang berdampak secara langsung maupun tidak langsung terhadap wilayah yang dilalui. Pada tanggal 1-6 Januari 2019, siklon tropis Pabuk muncul di wilayah Laut Cina Selatan dengan pergerakan ke arah barat dan kecepatan angin maksimumnya mencapai 64 knots. Penelitian ini dilakukan untuk mengkaji dampak yang ditimbulkan oleh siklon tropis Pabuk terhadap kondisi atmosfer dan gelombang laut di wilayah Kepulauan Riau. Penelitian ini menggunakan analisis indeks konvektif dari data citra satelit Himawari-8 kanal IRI dan analisis sebaran hujan menggunakan data pengamatan curah hujan dari beberapa stasiun meteorologi yang ada di Kepulauan Riau. Data reanalisis European Centre for Medium-Range Weather Forecast (ECMWF) berupa kelembaban udara, vertical velocity, dan divergensi diolah untuk menggambarkan kondisi atmosfer pada masa hidup siklon tropis Pabuk. Data gelombang Wavewatch-III digunakan untuk menggambarkan kondisi gelombang laut di sekitar wilayah Kepulauan Riau. Hasil penelitian menunjukkan bahwa aktifnya siklon tropis Pabuk berdampak terhadap pertumbuhan awan konvektif yang menimbulkan hujan ringan hingga sedang yang cukup merata di wilayah Kepulauan Riau. Selain itu, berdampak juga pada potensi terjadinya gelombang tinggi mencapai 4,5 meter di sebelah utara Perairan Anambas dan 7,0 meter di sebelah timur laut Perairan Natuna.
\end{abstract}

Kata Kunci: Siklon tropis, citra satelit, tinggi gelombang 


\section{PENDAHULUAN}

Siklon tropis merupakan fenomena meteorologis yang sangat potensial menimbulkan dampak kerusakan pada daerah yang dilaluinya. Siklon tropis dikategorikan sebagai sistem tekanan rendah dengan skala sinoptik yang tumbuh di atas perairan hangat dengan wilayah blok awan konvektif dengan kecepatan angin maksimum berkisar 34 knots atau lebih. Masa hidup suatu siklon berkisar 3 hingga 18 hari (Syaifullah, 2015). Dampak siklon tropis berkisar pada radius antara $2^{\circ}$ hingga $4^{\circ}$ dari pusatnya dimana pola pembentukan badai dapat mencapai radius $12^{\circ}$ atau lebih (Sani dan Marzuki, 2015). Secara teoritis wilayah Indonesia bebas dari siklon tropis dikarenakan faktor koriolis muka bumi bernilai kecil, namun tetap akan memiliki dampak tidak langsung dari pertumbuhan siklon.

Dampak dari suatu siklon tropis di suatu wilayah bergantung pada jenis badai, topografi, jarak dari badai, dan kondisi atmosfer global (Prasetya, dkk., 2014). Energi suatu siklon diperoleh dari lautan hangat $\left(26.5^{\circ} \mathrm{C}\right.$ atau lebih) sehingga siklon akan melemah memasuki perairan dingin atau daratan. Dampak dari suatu siklon dapat berupa: angin kencang, hujan deras yang cukup lama sehingga memicu terjadinya banjir, gelombang tinggi, dan gelombang badai (storm surge). Gelombang merupakan faktor yang cukup penting dalam pelayanan informasi meteorologi kelautan. Gelombang laut yang cukup tinggi dapat berdampak terhadap aktivitas kelautan dan transportasi laut antar pulau (Mahsunah, dkk., 2019).
Dampak siklon tropis dipengaruhi posisi dan intensitas siklon dan juga tergantung pada faktor sirkulasi udara di wilayah Indonesia (Perawiska, dkk. 2018). Ketika ada indikasi tumbuh siklon di beberapa wilayah kecenderungan cuacanya akan memburuk dan berdampak pula terhadap gelombang tinggi di laut. Daerah pertumbuhan siklon tropis paling subur di dunia adalah Samudera Hindia dan perairan barat Australia (Haryani dan Zubaidah, 2012). Pada dasarnya perairan Indonesia memiliki variabilitas rendah dan cenderung konstan sepanjang tahun namun ketika terdapat pertumbuhan siklon tropis di sekitar wilayah Indonesia maka dapat memicu gelombang tinggi (Habibie, dkk., 2018).

Siklon tropis Pabuk muncul di Laut Cina Selatan (pesisir timur Thailand) pada tanggal 1-6 Januari 2019 dengan pergerakan ke arah barat (Gambar 1). Siklon Tropis Pabuk diawali dengan munculnya pusat tekanan rendah di Laut Cina Selatan (di sebelah timur laut Pulau Natuna) dan menguat menjadi tropical depression dengan kecepatan angin berkisar 35 knot pada tanggal 31 Desember 2018. Sehari kemudian pusat tekanan rendah tersebut dengan cepat semakin menguat menjadi tropical storm dengan kecepatan angin berkisar 40-60 knots. Badai tersebut terus menguat menjadi tropical cyclone dengan kecepatan angin berkisar 64 knots atau lebih pada tanggal 02 Januari 2019 dan diberi nama siklon tropis Pabuk. Penelitian ini akan mengkaji dampak yang ditimbulkan dari siklon tropis Pabuk terhadap kondisi atmosfer dan gelombang laut di Perairan Kepulauan Riau.

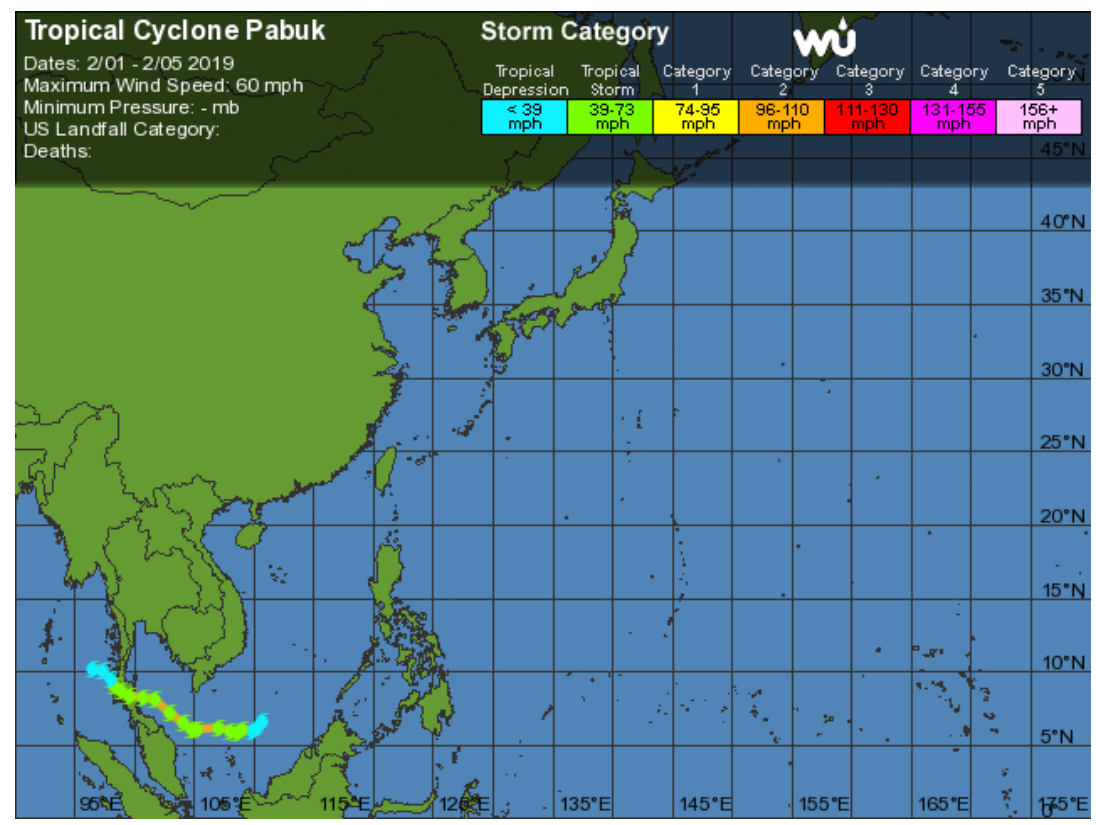

Gambar 1. Prakiraan lintasan siklon tropis Pabuk

(Sumber: Wunderground, 2020) 


\section{METODOLOGI}

Penelitian ini dilakukan di wilayah Perairan Provinsi Kepulauan Riau yang terletak pada koordinat antara 0440' LU - 00²9' LS dan 103²2' - 10940' BT. Penelitian ini akan mengkaji dampak dari siklon tropis Pabuk yang berlangsung pada tanggal 1-6 Januari 2019 terhadap kondisi atmosfer di wilayah Kepulauan Riau serta pengaruhnya terhadap tinggi gelombang di Perairan Kepulauan Riau. Penelitian ini akan mengkaji bagaimana sebaran awan konvektif pada saat kejadian dengan menggunakan data citra satelit Himawari-8 kanal IR1 dimana dari data tersebut akan diolah data indeks konvektif. Indeks konvektif dihitung dari selisih antara $255 \mathrm{~K}$ dan TBB (Temperature of Black Body) dimana TBB adalah suhu puncak awan dalam satuan Kelvin.

Pertumbuhan awan konvektif yang cukup giat akan menyebabkan peluang tejadinya hujan cukup besar. Untuk mengetahui kondisi sebaran hujan yang terjadi di wilayah Kepulauan Riau pada masa hidup siklon tropis Pabuk, dapat diamati dari data curah hujan pada setiap stasiun meteorologi yang tersebar di Kepulauan Riau. Data curah hujan diperoleh dari http://bmkgsoft.database.bmkg.go.id/. Kondisi curah hujan untuk: Pulau Batam diwakilkan oleh Stasiun Meteorologi Hang Nadim, Pulau Karimun diwakilkan oleh Stasiun Meteorologi Raja Haji Abdullah Tanjung Balai Karimun, Pulau Bintan diwakilikan oleh Stasiun Meteorologi Raja Haji Fisabilillah Tanjungpinang, Pulau Lingga-Singkep diwakilkan oleh Stasiun Meteorologi Dabo Singkep, Pulau Anambas diwakilkan oleh Stasiun Meteorologi Tarempa, dan Pulau Natuna diwakilkan oleh Stasiun Meteorologi Ranai.

Kondisi atmosfer pada masa hidup siklon tropis Pabuk akan diinterpretasikan menggunakan data reanalysis Era-Interim dari European Centre for Medium-Range Weather Forecasts (ECMWF) dengan resolusi spasial $0.125^{\circ} \times 0.125^{\circ}$ dimana resolusi temporal 6 jam dan level 1000 mb hingga 100 mb. Adapun data reanalysis yang digunakan yaitu: kelembaban udara (relative humidity), vertical velocity, dan divergensi. Selanjutnya, dampak siklon yang diamati yaitu bagaimana kondisi gelombang laut di wilayah perairan di sekitar Provinsi Kepulauan Riau. Data gelombang yang digunakan yaitu data Wavewatch III yang diperoleh dari http://peta-maritim.bmkg.go.id/render/. Datadata reanalysis dalam penelitian ini akan diolah menggunakan software GrADS (The Grid Analysis and Display System) untuk memanipulasi dan visualisasi data, sedangkan data .txt akan diolah menggunakan Microsoft Excel.

\section{HASIL PENELITIAN DAN PEMBAHASAN}

\section{Analisis Indeks Konvektif}

Aktivasi suatu siklon berdampak terhadap penumpukan massa udara di sekitarnya. Berdasarkan hasil olahan data satelit Himawari8 kanal IR1 dengan mengolah indeks konvektif (Gambar 2), dapat dilihat adanya pertumbuhan awan konvektif sebagai dampak dari adanya daerah konvergensi yang diakibatkan oleh siklon tropis Pabuk. Analisis indeks konvektif digunakan untuk mengetahui arus konveksi yang terjadi pada masa hidup siklon tropis Pabuk. Semakin besar nilai indeks konvektif menunjukkan arus konveksi yang sangat kuat di dalam suatu sistem konvektif. Hal tersebut berdampak terhadap ketidakstabilan kondisi atmosfer, sehingga wilayah tersebut akan mendapatkan curah hujan yang cukup banyak. Indeks konvektif yang fluktuatif terjadi sebagai dampak dari pembentukan suatu siklon (Ismail, dkk. 2017). Gambar 2 menunjukkan sebaran nilai indeks konvektif yang terjadi pada masa hidup siklon tropis Pabuk dari awal pembentukan siklon, proses intensifikasi, tahap matang, hingga tahap disipasi (peluruhan).

Pada tanggal 1 Januari 2019, siklon tropis Pabuk dalam kategori tropical storm. Indeks konvektif yang terdeteksi berkisar 40 hingga 80 di sekitar radius pertumbuhan siklon tropis Pabuk (di sekitar Laut Cina Selatan), sedangkan nilai indeks di sekitar wilayah Kepulauan Riau yaitu kurang dari 30. Pada tanggal 2-3 Januari 2019, siklon tropis Pabuk dalam kategori tropical cyclone. Indeks konvektif yang terdeteksi di wilayah Kepulauan Riau berkisar 30 hingga 60. Sebaran dan nilai indeks konvektif yang meningkat menunjukkan adanya pertumbuhan awan konvektif yang cukup signifikan (Sugianto, dkk., 2018). Hal tersebut dapat memicu peluang banyaknya kejadian cuaca ekstrem seperti: angin kencang, hujan lebat, maupun gelombang tinggi. Indeks konvektif berangsur-angsur berkurang di tanggal 4-5 Januari 2019 sebagai dampak dari pengaruh siklon tropis Pabuk yang sangat kecil. Hal tersebut terjadi karena posisi siklon mulai menjauhi wilayah Kepulauan Riau. Kondisi tersebut terjadi dikarenakan tingkat siklon tropis Pabuk dalam kategori tropical storm dan siklon mulai memasuki tahap dissipasi atau punah pada tanggal 6 Januari 2019 (kategori tropical depression) 


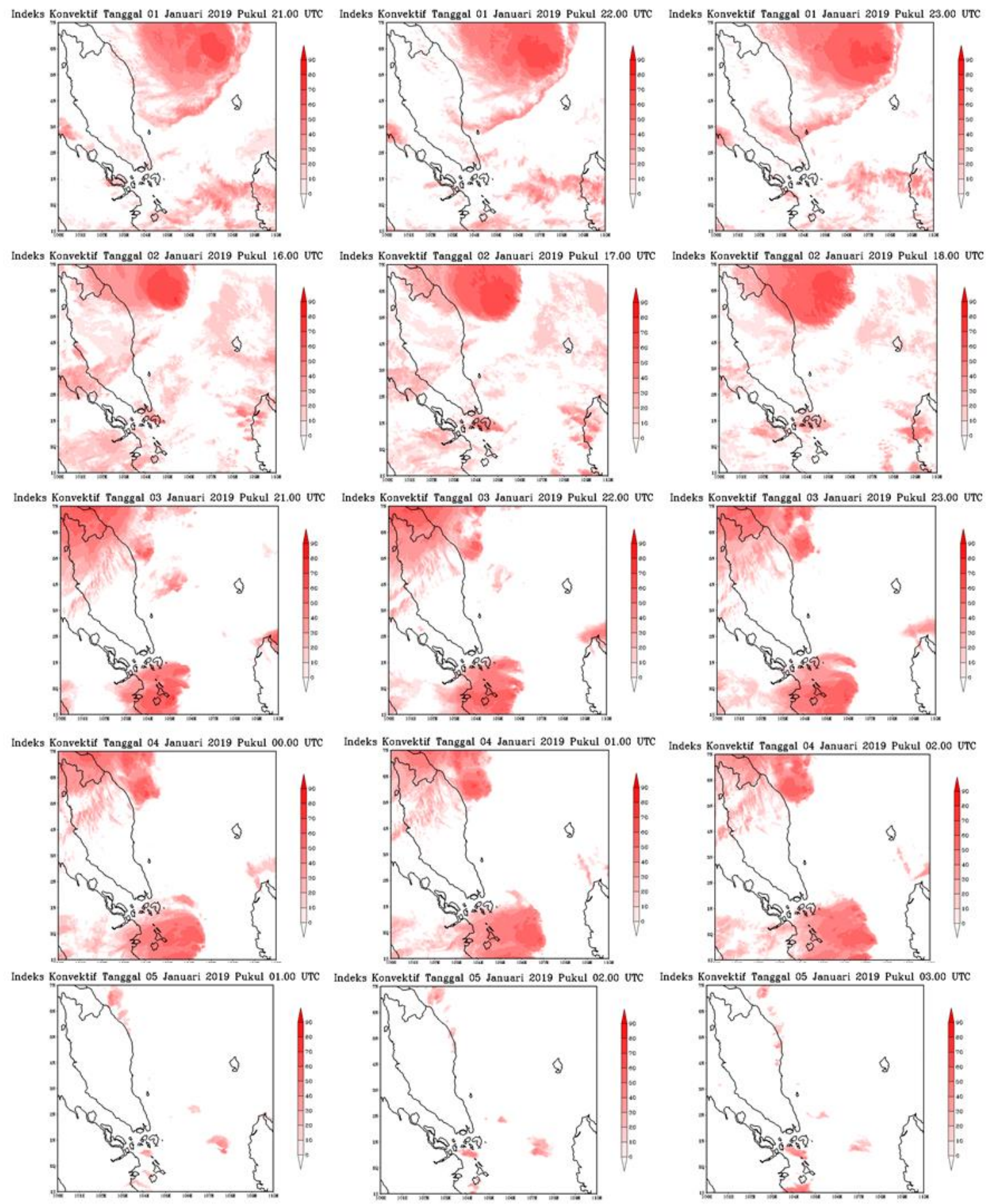

Gambar 2. Indeks konvektif pada masa hidup siklon tropis Pabuk tanggal 1-6 Januari 2019 (Sumber: Pengolahan Data, 2020)

Konvektifitas yang cukup kuat antara lautan dan atmosfer menyebabkan pertumbuhan awanawan konvektif yang cukup banyak (Tjasyono, 2004). Pertumbuhan awan konvektif menyebabkan peluang terjadinya hujan cukup banyak. Gambar 3 menjelaskan dampak dari siklon tropis Pabuk pada masing-masing fase pertumbuhan siklon terhadap curah hujan per 6 jam yang diukur di setiap stasiun meteorologi yang tersebar di Kepulauan Riau. Pada saat siklon tropis
Pabuk dikategorikan tropical storm pada tanggal 1 Januari 2019, dapat dilihat hujan hanya terjadi di wilayah Pulau Batam, Pulau Karimun, dan Pulau Lingga. Indeks konvektif yang teramati berkisar 10 hingga 30.

Pada saat siklon tropis Pabuk dikategorikan tropical cyclone pada tanggal 2-3 Januari 2019, dapat dilihat hujan terjadi hampir cukup merata di setiap wilayah Kepulauan Riau. Sebaran awan konvektif menutupi wilayah Kepulauan Riau 
menyebabkan hujan yang tercatat dikategorikan hujan ringan hingga sedang. Curah hujan terbanyak terjadi di wilayah Pulau Natuna dan Pulau Anambas, sebagai dampak dari posisi wilayah tersebut dekat dengan koordinat pertumbuhan siklon tropis Pabuk. Indeks konvektif yang teramati berkisar 30 hingga 60. Pada saat siklon tropis Pabuk dikategorikan kembali menjadi tropical storm pada tanggal 4-5 Januari 2019, hujan terjadi hanya di wilayah Pulau Lingga dan Pulau Bintan. Sebaran awan konvektif cukup giat terjadi di wilayah tersebut sehingga indeks konvektif yang teramati berkisar 20 hingga 50.

Curah Hujan per 6 jam di Kepulauan Riau Pada Masa Hidup Siklon Tropis Pabuk

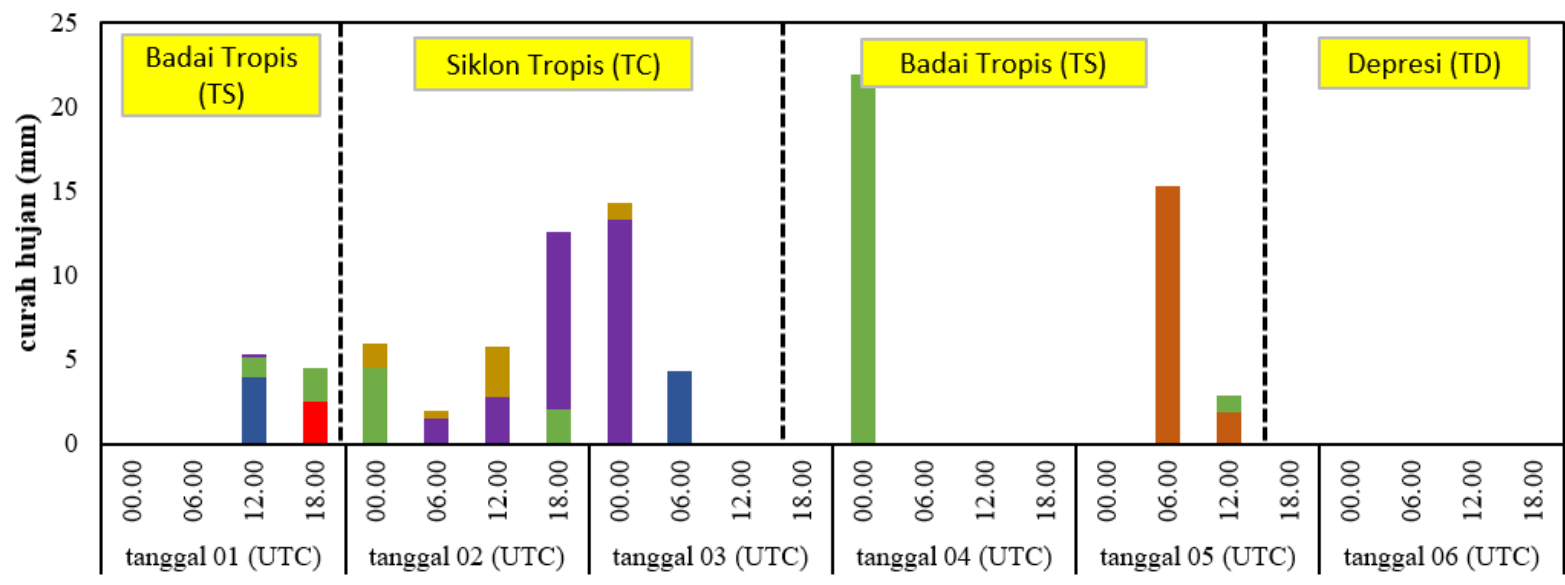

Januari 2019

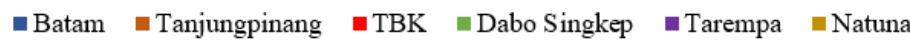

Gambar 3. Curah hujan per 6 jam di Kepulauan Riau pada masa hidup siklon tropis Pabuk pada tanggal 1-6 Januari 2019 (Sumber: Pengolahan Data, 2020)

\section{Analisis Kondisi Atmosfer}

1. Kelembaban udara (relative humidity)

Banyaknya uap air di atmosfer merupakan salah satu syarat pendukung untuk pertumbuhan awanawan konvektif. Semakin basah lapisan atmosfer dari permukaan hingga lapisan atas menunjukkan kondisi atmosfer dalam kondisi labil. Gambar 4 menunjukkan kondisi kelembaban udara secara vertikal di setiap wilayah pulau yang ada di Kepulauan Riau pada masa hidup siklon tropis Pabuk untuk tanggal 1-6 Januari 2019 pada lapisan $1000 \mathrm{mb}$ hingga $100 \mathrm{mb}$. Kondisi kelembaban udara pada tanggal 1 Januari 2019 (kategori tropical storm), seluruh wilayah di Kepulauan Riau berkisar 75-100 \%. Hal tersebut dapat memicu pertumbuhan awan konvektif yang cukup banyak.

Pada dasarnya, nilai kelembaban udara yang cukup tinggi mengindikasikan adanya potensi terjadinya hujan lebat serta dapat mendukung proses kondensasi di dalam pembentukan awan- awan tipe cumuliform seperti awan Cumulonimbus. Kondisi kelembaban udara pada tanggal 2-3 Januari 2019 (kategori tropical storm), seluruh wilayah di Kepulauan Riau berkisar 60-90 $\%$. Kondisi kelembaban udara yang sangat lembab menunjukkan besarnya peluang terjadinya hujan. Kondisi kelembaban udara pada tanggal 4-5 Januari 2019 (kategori tropical storm), seluruh wilayah di Kepulauan Riau berkisar 55-80 \% dimana rata-rata pada lapisan 800 hingga $400 \mathrm{mb}$ berkisar 55-70 \%. Hal tersebut hampir sama ditunjukkan oleh kondisi kelembaban udara pada tanggal 6 Januari 2019 (kategori tropical depression) dimana seluruh wilayah di Kepulauan Riau berkisar 55-85 \%. Kondisi tersebut menunjukkan intensitas uap air tiap lapisan (lapisan $600 \mathrm{mb}$ hingga $100 \mathrm{mb}$ ) kurang basah sehingga peluang pertumbuhan awan konvektif sangat kecil. Hal tersebut berdampak terhadap kecilnya peluang terjadinya hujan di wilayah Kepulauan Riau. 

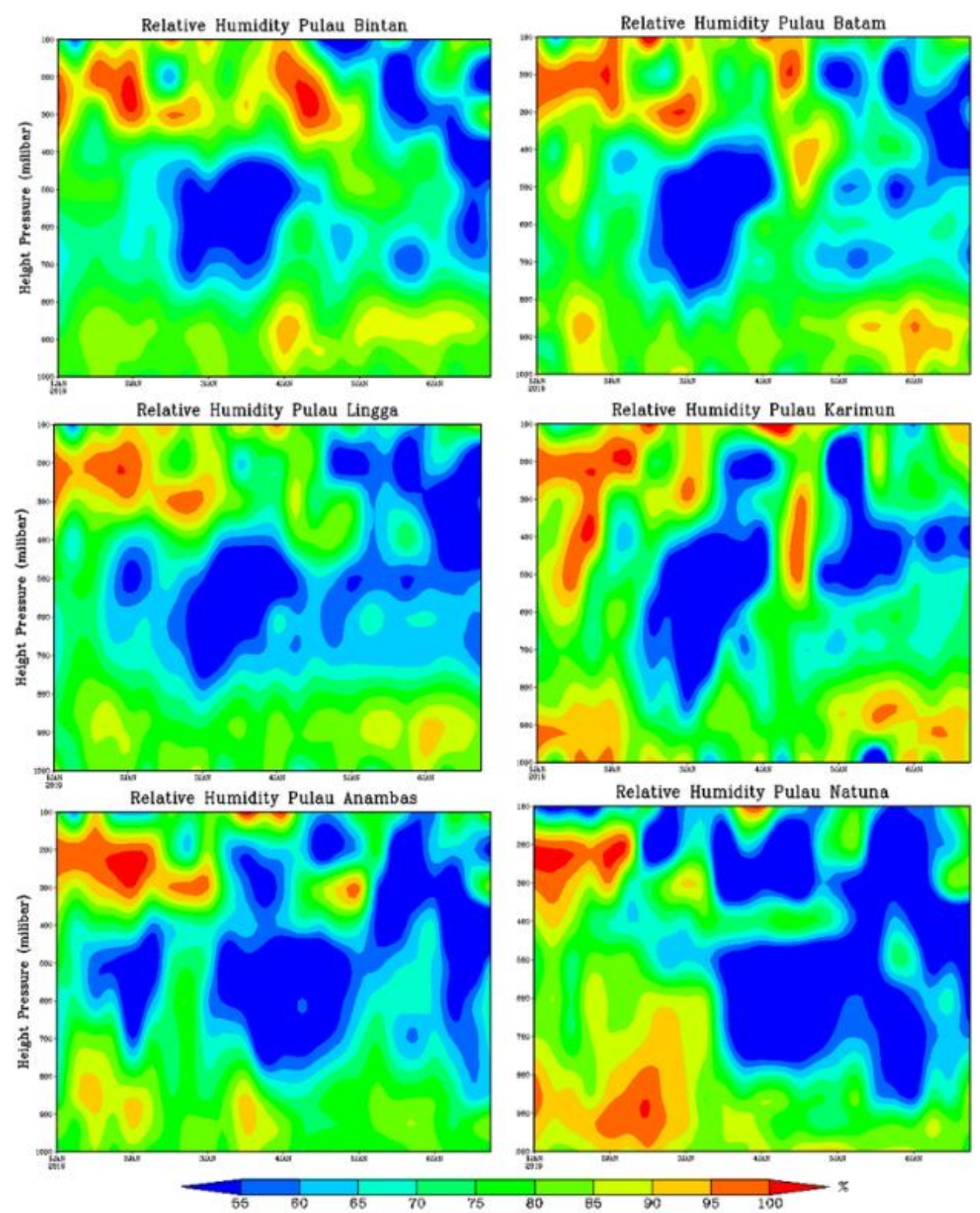

Gambar 4. Nilai kelembaban udara (relative humidity) di wilayah Kepulauan Riau pada saat masa hidup siklon tropis Pabuk pada tanggal 1-6 Januari 2019

(Sumber: Pengolahan Data, 2020)

\section{Vertical velocity}

Semakin kecil nilai vertical velocity menunjukkan giatnya pergerakan udara vertikal ke atas (updraft) yang membawa massa udara lembab hingga ke lapisan atas. Dampaknya terhadap giatnya pertumbuhan awan konvektif seperti awan Cumulonimbus (Dewi dan Kristianto, 2017). Kondisi tersebut dapat menyebabkan peluang cuaca buruk seperti hujan lebat disertai angin kencang dapat terjadi. Gambar 5 menunjukkan nilai vertical velocity secara vertikal di setiap wilayah pulau yang ada di Kepulauan Riau pada masa hidup siklon tropis Pabuk untuk tanggal 1-6 Januari 2019 pada lapisan 1000 mb hingga 100 mb. Pada tanggal 1 Januari 2019 (kategori tropical storm), pertumbuhan awan tipe cumuliform dapat memicu terjadinya hujan di wilayah Kepulauan Riau. Pada saat hujan terjadi, terdapat aktivitas kenaikan massa udara pada lapisan $925 \mathrm{mb}$ hingga $300 \mathrm{mb}$ dimana nilai vertical velocity berkisar -0.4 $\mathrm{Pa} / \mathrm{s}$ hingga $-0.1 \mathrm{~Pa} / \mathrm{s}$. Pada tanggal 2-3 Januari 2019 (kategori tropical storm), nilai vertical velocity berkisar $-0.3 \mathrm{~Pa} / \mathrm{s}$ hingga $0.2 \mathrm{~Pa} / \mathrm{s}$. Pada tanggal 4-5 Januari 2019 (kategori tropical storm) dan tanggal 6 Januari 2019 (kategori tropical depression), nilai vertical velocity berkisar $-0.2 \mathrm{~Pa} / \mathrm{s}$ hingga $0.3 \mathrm{~Pa} / \mathrm{s}$. Kondisi tersebut menunjukkan nilai vertical velocity semakin besar (bernilai positif), sehingga peluang terjadinya updraft di dalam awan sangat kecil. Hal tersebut berdampak terhadap kurang giatnya pertumbuhan awan tipe cumuliform sehingga peluang terjadinya hujan juga cukup kecil. 

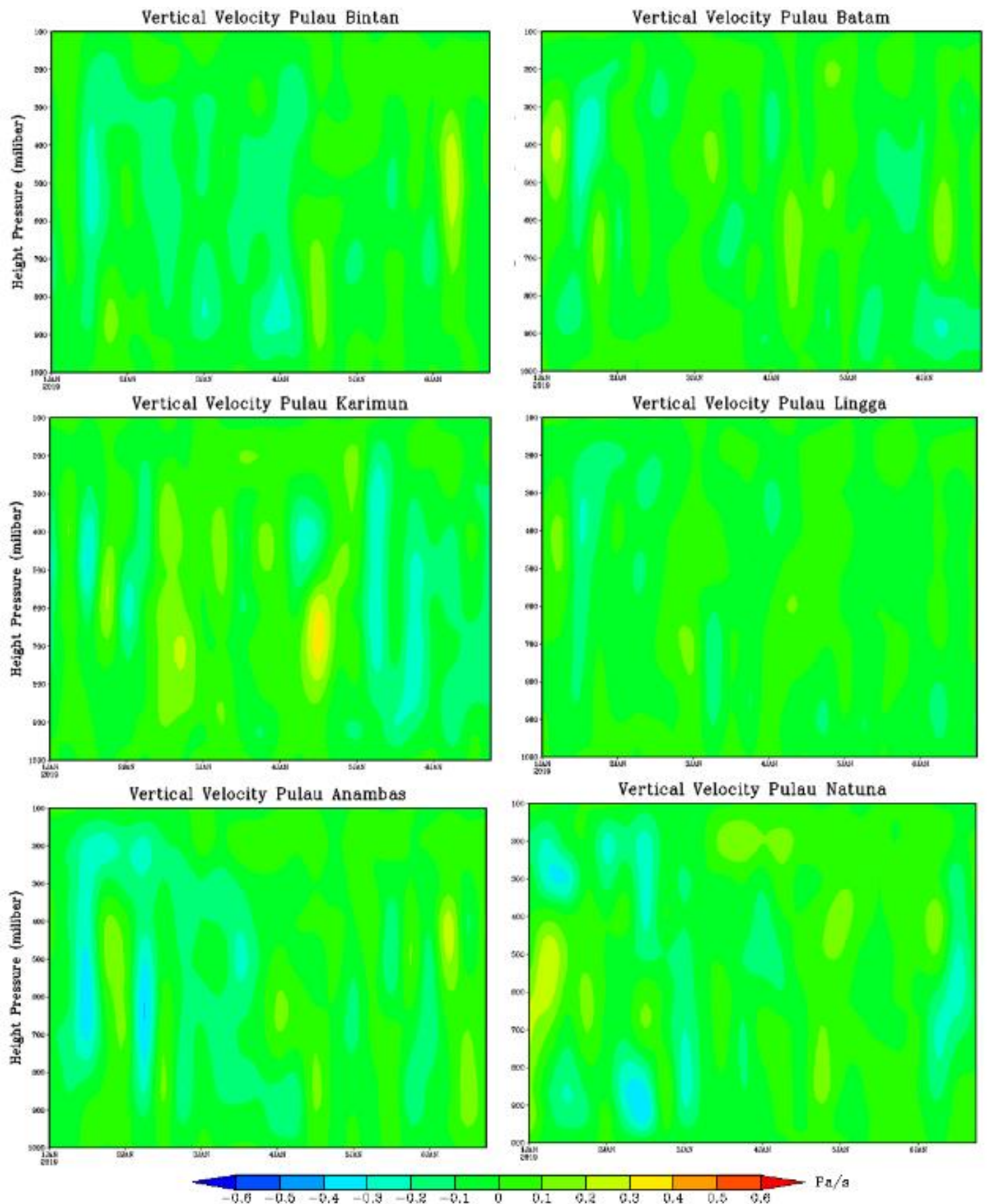

Gambar 5. Nilai vertical velocity di wilayah Kepulauan Riau pada saat masa hidup siklon tropis Pabuk pada tanggal 1-6 Januari 2019

(Sumber: Pengolahan Data, 2020)

\section{Divergensi}

Semakin kecil nilai divergensi menunjukkan terdapat pemampatan massa udara berupa konvergensi. Kondisi tersebut dapat berdampak terhadap potensi terjadinya pengangkatan massa udara (updraft) pada awan yang terbentuk. Gambar 6 menunjukkan nilai divergensi secara vertikal di setiap wilayah pulau yang ada di Kepulauan Riau pada masa hidup siklon tropis Pabuk untuk tanggal 1-6 Januari 2019 pada lapisan $1000 \mathrm{mb}$ hingga $100 \mathrm{mb}$. Sebaran nilai divergensi di wilayah Kepulauan Riau yang teramati pada masa hidup siklon tropis Pabuk dari proses intensifikasi, tahap matang, hingga tahap disipasi yaitu berkisar $10^{-7} / \mathrm{s}$ hingga $10^{-5} / \mathrm{s}$. Kondisi tersebut menunjukkan nilai divergensi semakin besar (bernilai positif), sehingga peluang terjadinya updraft di dalam awan sangat kecil. Indikasi adanya pemampatan massa udara hingga lapisan atas bernilai kecil. Berdasarkan nilai divergensi, peluang pertumbuhan awan-awan penghasil hujan dikategorikan cukup kecil. 

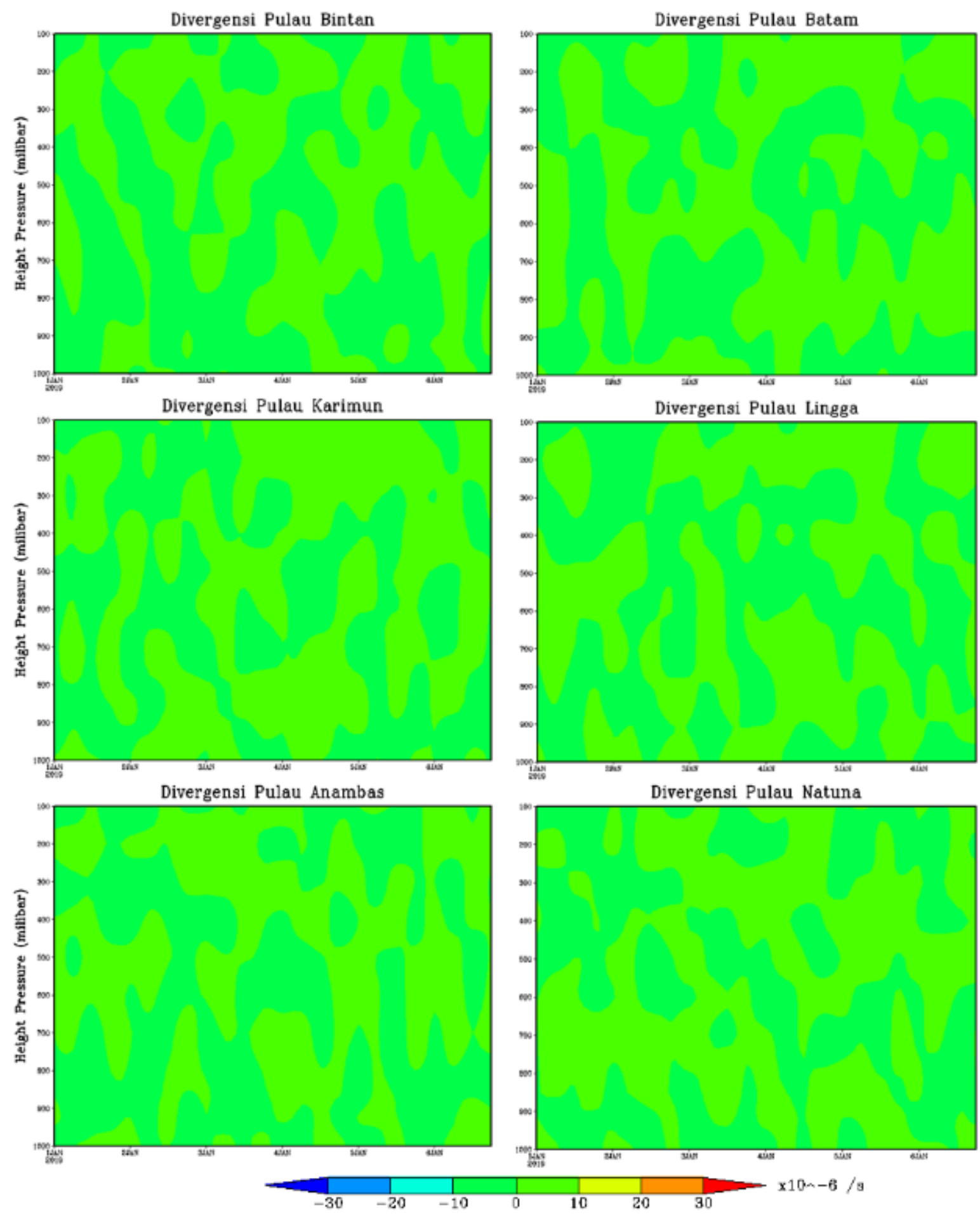

Gambar 6. Nilai divergensi di wilayah Kepulauan Riau pada saat masa hidup siklon tropis Pabuk pada tanggal 1-6 Januari 2019

(Sumber: Pengolahan Data, 2020)

\section{Analisis Kondisi Gelombang Laut}

Provinsi Kepulauan Riau yang sebagian besar wilayahnya berbatasan langsung dengan perairan menjadikan laut sebagai jalur transportasi yang memegang peranan penting sebagai penghubung antar pulau. Setiap pelayanan dan kegiatan kelautan lainnya dapat direncanakan dengan baik dan efisien apabila tersedia informasi mengenai karakteristik variabilitas gelombang di seluruh wilayah perairan. Sesuai dengan Guide The Marine Meteorological Services: Third Edition (WMO, 2001), hampir semua jenis kapal yang sedang berlayar akan terpengaruh oleh gelombang dengan tinggi berkisar 2 meter atau lebih. Kurniawan, dkk. (2012) dalam penelitiannya menyatakan pola gelombang ekstrem di Perairan Laut Cina Selatan akan serupa dengan pola tinggi gelombang rataratanya pada bulan Desember hingga Februari. 
Aktivasi monsun Asia pada periode DesemberJanuari-Februari (DJF) menyebabkan intensifikasi gelombang laut yang cukup signifikan di wilayah Perairan Kepulauan Riau bagian utara yang berbatasan langsung dengan Laut Cina Selatan. Menurut penelitian Habibie, dkk. (2018), rata-rata gelombang tinggi pada saat aktifnya monsun Asia pada perairan: Laut Cina Selatan berkisar 1 hingga 2,5 meter dan Pulau Natuna bagian utara berkisar 1,5 hingga 2,0 meter. Pada periode monsun Asia memasuki wilayah Indonesia, daerah rawan gelombang tinggi akan terjadi di wilayah Perairan Anambas-Natuna bagian utara. Hal tersebut sebagai dampak dari masuknya angin utara (cross equatorial flow) ke wilayah Kepulauan Riau.

Munculnya siklon tropis Pabuk pada tanggal 16 Januari 2019 menyebabkan giatnya pertumbuhan awan konvektif sehingga peluang terjadinya hujan lebat disertai angin kencang dapat terjadi di wilayah Kepulauan Riau. Hal tersebut juga berdampak terhadap gelombang tinggi yang berpeluang terjadi di Perairan Kepulauan Riau. Menurut Haryanto, dkk. (2017), peningkatan skala suatu siklon dapat berdampak terhadap peluang terjadinya gelombang tinggi di suatu wilayah perairan cukup besar.
Berdasarkan Gambar 7 dan 8, tinggi gelombang signifikan sudah mulai meningkat sejak tanggal 1 Januari 2019 khususnya di wilayah Perairan Natuna bagian utara (berbatasan langsung dengan Laut Cina Selatan) dimana tinggi gelombang signifikan mencapai 7,0 meter. Selain itu, gelombang tinggi mencapai 4,5 meter juga terjadi di wilayah Perairan Anambas. Hal tersebut terjadi dikarenakan pergerakan siklon tropis Pabuk sedang dalam fase melewati wilayah Laut Cina Selatan. Tinggi gelombang signifikan mulai normal kembali dimulai pada tanggal 4 Januari 2019. Hal tersebut sebagai dampak dari pergerakan siklon tropis Pabuk yang mulai menjauh dari wilayah Kepulauan Riau dimana kondisi kecepatan angin dari dampak siklon tersebut mulai melemah hingga tanggal 6 Januari 2019, sehingga tinggi gelombang di Perairan Anambas-Natuna juga mulai berkurang dimana berkisar 1,0 meter hingga 2,3 meter. Pada dasarnya, aktifnya siklon tropis Pabuk tidak terlalu berdampak terhadap gelombang tinggi di wilayah perairan: Batam, Bintan, Karimun, dan Lingga. Tinggi gelombang yang teramati pada wilayah tersebutberkisar 0,1 meter hingga 1,2 meter.

\section{Rata-rata Tinggi Gelombang di Perairan Kepulauan Riau Pada Masa Hidup Siklon Pabuk}

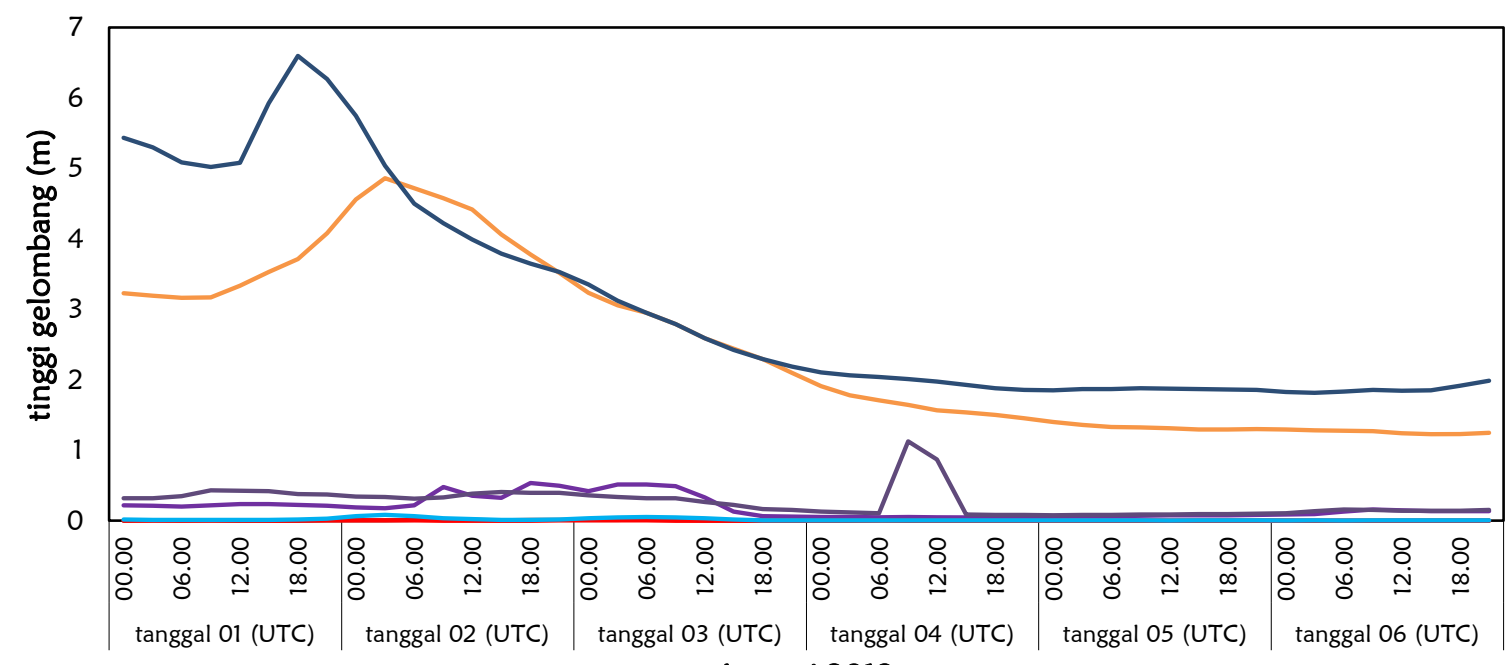

Januari 2019

$$
\text { - Batam Bintan — TBK Lingga - Anambas - Natuna }
$$

Gambar 7. Rata-rata tinggi gelombang di Perairan Kepulauan Riau pada masa hidup siklon tropis Pabuk pada tanggal 1-6 Januari 2019

(Sumber: Pengolahan Data, 2020) 


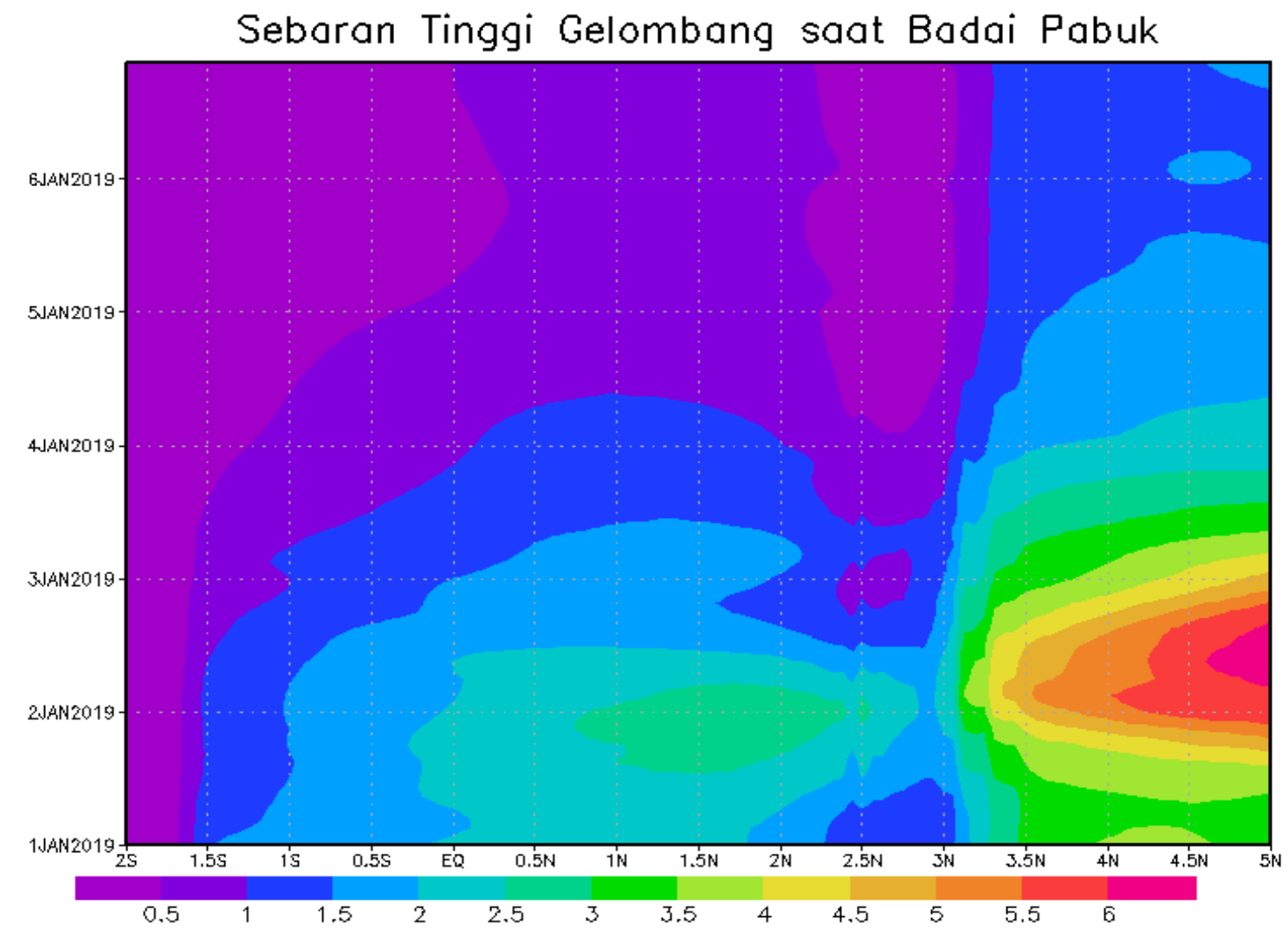

Gambar 8. Sebaran tinggi gelombang di Perairan Kepulauan Riau pada masa hidup siklon tropis Pabuk pada tanggal 1-6 Januari 2019

(Sumber: Pengolahan Data, 2020)

\section{KESIMPULAN}

Siklon tropis Pabuk yang terbentuk di Laut Cina Selatan pada tanggal 1-6 Januari 2019 berdampak terhadap pertumbuhan awan konvektif di wilayah Kepulauan Riau sehingga peluang terjadinya cuaca ekstrem seperti hujan lebat disertai angin kencang di beberapa wilayah daratan di Kepulauan Riau dikategorikan cukup besar. Selain itu, peluang terjadinya gelombang tinggi di Perairan Kepulauan Riau juga cukup besar khususnya di Perairan Anambas-Natuna bagian utara yang berbatasan langsung dengan Laut Cina Selatan. Pada saat masa transisi proses intensifikasi siklon tropis Pabuk menjadi tahap matang berdampak terhadap potensi gelombang tinggi mencapai 7,0 meter di Perairan Natuna dan mencapai 4,5 meter di Perairan Anambas. Pada saat siklon tropis Pabuk dikategorikan tropical cyclone pada tanggal 2-3 Januari 2019, hujan terjadi hampir cukup merata di setiap wilayah Kepulauan Riau. Sebaran awan konvektif menutupi wilayah Kepulauan Riau meyebabkan hujan yang tercatat dikategorikan hujan ringan hingga sedang. Kondisi tersebut didukung dengan nilai indeks konvektif yang teramati berkisar 30 hingga 60, nilai kelembaban udara berkisar 60-90\%, nilai vertical velocity berkisar $-0.3 \mathrm{~Pa} / \mathrm{s}$ hingga $0.2 \mathrm{~Pa} / \mathrm{s}$, dan nilai divergensi berkisar $10^{-7} / \mathrm{s}$ hingga $10^{-5} / \mathrm{s}$. Pada dasarnya, kondisi kelembaban udara yang cukup basah dan nilai vertical velocity yang semakin kecil hingga lapisan atas mengindikasikan giatnya pertumbuhan awan tipe cumuliform khususnya awan Cumulonimbus, namun nilai divergensi yang semakin besar mengindikasikan peluang pertumbuhan awan penghasil hujan dikategorikan cukup kecil.

\section{UCAPAN TERIMA KASIH}

Terima kasih kepada Badan Meteorologi Klimatologi dan Geofisika (BMKG) yang telah membantu memberikan data citra satelit Himawari-8, data curah hujan yang tersedia di Database BMKCSoft, dan data gelombang hasil keluaran Wavewatch-III yang penulis butuhkan sehingga penelitian ini dapat diselesaikan.

\section{DAFTAR PUSTAKA}

BMKG. (2020). Tinggi Gelombang di Perairan Kepulauan Riau. Cited in https://petamaritim.bmkg.go.id/render. Januari 2020

BMKG. (2020). Curah Hujan yang Tercatat di Stasiun Meteorologi yang ada di wilayah Kepulauan Riau. Cited in http://bmkgsoft.database.bmkg.go.id/. Januari 2020 
Dewi, A.M. \& Kristianto, A. (2017). Analisis Transport Uap Air di Kupang Saat Terjadi Siklon Tropis Narelle (Studi Kasus Tanggal 6 Januari 2013). Jurnal Meteorologi Klimatologi dan Geofisika. 4(1), 8-16.

Habibie, M.N., Fitria, W., \& Sofian, I. (2018). Kajian Indeks Variabilitas Tinggi Gelombang Signifikan di Indonesia. Jurnal Segara. 14(3), 159-168.

Haryani, N.S. \& Zubaidah, A. (2012). Dinamika Siklon Tropis di Asia Tenggara Menggunakan Data Penginderaan Jauh. Jurnal Ilmiah Widya. 29(324).

Haryanto, Y.D., Fadlan, A., Hartoko, A., Anggoro, S. \& Zainuri, M. (2017). Dampak Siklon Tropis Quang Terhadap Tinggi Gelombang, Arus Laut dan Upwelling di Perairan Selatan Jawa. Jurnal Meteorologi dan Geofisika. 18(1), 45-54.

Ismail, P., Hidayat, N. M. \& Siadari, E.J. (2017). Analisis Siklon Tropis Nock-Ten Berbasis Data Satelit Himawari. Jurnal Meteorologi Klimatologi dan Geofisika. 4(3), 16-25.

Kurniawan, R., Habibie, M.N. \& Permana, S.D. (2012). Kajian Daerah Rawan Gelombang Tinggi di Perairan Indonesia. Jurnal Meteorologi dan Geofisika. 13(3), 201-212.

Mahsunah, O., Widagdo, S. \& Bintoro, R.S. (2019). Karakteristik Siklon Dahlia Terhadap Perubahan Tinggi Gelombang di Perairan Pesisir Selatan Jawa. Seminar Nasional Kelautan XIV, Surabaya 11 Juli 2019, 68-75.

Perawiska, E., Muliadi \& Adriat, R. (2018). Analisis Unsur Cuaca Pada Saat Kejadian Siklon Tropis Haiyan Menggunakan Model WRF (Weather Research and Forecasting). Prisma Fisika. 6(2), 129-136.

Prasetya, R., As'ari, \& Dayantolis, W. (2014). Analisis Dampak Siklon Tropis Nangka, Parma dan Nida pada Distribusi Curah Hujan di Sulawesi Utara. Jurnal Fisika dan Aplikasinya FMIPA ITS. 10(1), 1-9.

Sani, L.F. \& Marzuki. (2015). Pengaruh Badai Tropis Haiyan Terhadap Pola Hujan di Indonesia. Jurnal Fisika Unand. 4(2), $157-$ 166.

Sugianto, P.A., Azka, M.A., Mahubessy, R. \& Winarso, P.A. (2018). Kajian Kondisi Atmosfer di Wilayah Indonesia Saat Periode Aktifnya Badai Tropis Kai-Tak. Prosiding SNFA (Seminar Nasional Fisika dan Aplikasinya).

Syaifullah, M.D. (2015). Siklon Tropis, Karakteristik dan Pengaruhnya di Wilayah Indoensia Pada Tahun 2012. Jurnal Sains dan Teknologi Modifikasi Cuaca. 16(2), 6171.

Tjasyono, B.H.K. (2004). Klimatologi. Bandung: Penerbit ITB.

World Meteorological Organization (WMO). (2001). Guide The Marine Meteorological Services: Third Edition. WMO No. 471. Secretariat of the World Meteorological Organization. Geneva-Switzerland: Author.

Wunderground. (2020). Pabuk Tropical Cyclone. Cited in https://www.wunderground.com/hurrican e. Januari 2020 
